\title{
Innovative Biochemometric Approach to the Metabolite and Biological Profiling of the Balkan Thistle (Cirsium appendiculatum Griseb.), Asteraceae
}

\author{
Dimitrina Zheleva-Dimitrova ${ }^{1}$, , Gokhan Zengin ${ }^{2} \oplus$, Gunes $\mathrm{Ak}^{2}$, Kouadio Ibrahime Sinan ${ }^{2}$, \\ Mohamad Fawzi Mahomoodally ${ }^{3}{ }^{(D)}$, Reneta Gevrenova ${ }^{1}{ }^{D}$, Vessela Balabanova ${ }^{1}$, Alexandra Stefanova ${ }^{1}$, \\ Paraskev Nedialkov ${ }^{1}$ (D) and Yulian Voynikov ${ }^{4}$
}

Citation: Zheleva-Dimitrova, D. Zengin, G.; Ak, G.; Sinan, K.I.; Mahomoodally, M.F.; Gevrenova, R.; Balabanova, V.; Stefanova, A.; Nedialkov, P.; Voynikov, Y. Innovative Biochemometric Approach to the Metabolite and Biological Profiling of the Balkan Thistle (Cirsium appendiculatum Griseb.), Asteraceae. Plants 2021, 10, 2046. https:// doi.org/10.3390/plants10102046

Academic Editor: Ahmed A. Hussein

Received: 23 August 2021

Accepted: 24 September 2021

Published: 28 September 2021

Publisher's Note: MDPI stays neutral with regard to jurisdictional claims in published maps and institutional affiliations.

Copyright: (C) 2021 by the authors Licensee MDPI, Basel, Switzerland. This article is an open access article distributed under the terms and conditions of the Creative Commons Attribution (CC BY) license (https:// creativecommons.org/licenses/by/ $4.0 /)$.
1 Department of Pharmacognosy, Faculty of Pharmacy, Medical University-Sofia, 2 Dunav Str., 1000 Sofia, Bulgaria; rgevrenova@pharmfac.mu-sofia.bg (R.G.); vbalabanova@pharmfac.mu-sofia.bg (V.B.); al_stefanova@abv.bg (A.S.); pnedialkov@pharmfac.mu-sofia.bg (P.N.)

2 Biochemistry and Physiology Research Laboratory, Department of Biology, Science Faculty, Selcuk University, Konya 42130, Turkey; gokhanzengin@selcuk.edu.tr (G.Z.); akguneselcuk@gmail.com (G.A.); sinankouadio@gmail.com (K.I.S.)

3 Department of Health Sciences, Faculty of Medicine and Health Sciences, University of Mauritius, Réduit 80837, Mauritius; f.mahomoodally@uom.ac.mu

4 Department of Chemistry, Faculty of Pharmacy, Medical University-Sofia, Bulgaria 2 Dunav Str., 1000 Sofia, Bulgaria; voynikov_y@pharmfac.mu-sofia.bg

* Correspondence: dzheleva@pharmfac.mu-sofia.bg; Tel.: +35-989-825-4383

\begin{abstract}
The widespread genus Cirsium Mill. (Asteraceae) is renowned in traditional medicine. In the present study, an innovative biochemometric-assisted metabolite profiling of the flower heads, aerial parts and roots of Cirsium appendiculatum Griseb. (Balkan thistle) in relation to their antioxidant and enzyme inhibitory potential was developed. The workflow combines ultra-highperformance liquid chromatography-high-resolution mass spectrometry (UHPLC-HRMS) with partial least-square analysis to discriminate the herbal extracts and identify the most prominent biological activities. The annotation and dereplication of 61 secondary metabolites were evidenced, including 15 carboxylic (including hydroxybenzoic and hydroxycinnamic) acids and their glycosides, 11 acylquinic acids, 26 flavonoids and 9 fatty acids. All compounds were reported for the first time in the studied species. The root extract revealed the highest cupric and ferric reducing power (618.36 $\pm 5.17 \mathrm{mg} \mathrm{TE} / \mathrm{g}$ and $269.89 \pm 8.50 \mathrm{mg} \mathrm{TE} / \mathrm{g}$, respectively) and antioxidant potential in phosphomolybdenum $(3.36 \pm 0.15 \mathrm{mmol} \mathrm{TE} / \mathrm{g})$ as well as the most prominent enzyme inhibitory potential on $\alpha$-glucosidase $(0.72 \pm 0.07 \mathrm{mmol} \mathrm{ACAE} / \mathrm{g})$, acetylcholinesterase $(4.93 \pm 0.25 \mathrm{mg}$ GALAE/g) and butyrylcholinesterase ( $3.80 \pm 0.26 \mathrm{mg} \mathrm{GALAE} / \mathrm{g})$. Nevertheless, the flower heads were differentiated by their higher metal chelating activity $(32.53 \pm 3.51 \mathrm{mg}$ EDTAE/g) and total flavonoid content (46.59 $\pm 0.89 \mathrm{mgRE} / \mathrm{g})$. The partial least-square discriminant and heat-map analysis highlighted the root extract as the most active and a promising source of bioactive compounds for the therapeutic industry.
\end{abstract}

Keywords: Cirsium appendiculatum; UHPLC-HRMS; biochemometric; antioxidants; enzyme inhibitory activity; partial least-square discriminant analysis

\section{Introduction}

Profiling methods for the analysis of crude plant extracts have evolved into powerful tools for dereplication, quality assessment and metabolomics. This procedure enables recognition of known metabolites at the earliest stage of separation, avoiding the timeconsuming and expensive isolation of common constituents. The most current metabolite profiling studies are performed with state-of-the-art high-resolution LC-MS tools that apply the high resolution of ultra-high-performance liquid chromatography (UHPLC) for 
the chromatographic resolution of isomers, and high-resolution MS methods for molecular formula assignment [1]. In particular, the hybrid quadrupole-orbitrap has high mass resolution and accuracy in MS non-targeted profilings of specialized (secondary) natural products in crude extracts [2]. In this context, biochemometrics approaches, which rely on the use of statistical modelling tools to correlate metabolite profiles with biological datasets, are very useful for assigning biological activity to a particular compound detected from complex mixtures.

The widespread genus Cirsium Mill. (thistle) is one of the biggest genera in Asteraceae family (subfamily: Carduoideae Cass. Ex Sweet, tribe: Cardueae Cass., subtribe: Carduinae (Cass.) Dumort, sect. Cirsium). It includes about 250 species spread throughout Europe, North Africa, East Asia, Central Asia, SW Asia and North and Central America [3,4]. Its species have been used for many years as a traditional herbal medicine. As the origin of the name suggests ("khirsos" in Greek means "swollen veins"), the genus Cirsium has been known for centuries for its usage against varicose diseases, to relieve pain [4]. According to the ethnopharmacological relevance, the species is also valued for the treatment of numerous ailments due to its diuretic, astringent, anti-inflammatory, anti-melanogenesis, anti-tumor and anxiolitic activities as well as its activity against nonalcoholic fatty liver disease [5,6]. Additionally, some Cirsium species are used as a food source. Receptacles of $C$. spinosissimum have been traditionally eaten similarly to artichoke leaves by alpine populations [7]. Moreover, Cirsium species are valuable to the honey industry as they produce a good supply of nectar and pollen. In the past decade, invasive exotic species, such as Eurasian thistles, present a major threat to sustained productivity and biodiversity in the United States, and different Cirsium species have been assessed for biological control as weeds [8].

The taxon is characterized by the presence of a large number of secondary metabolites such as phenolic acids, flavonoids, sterols, triterpenes, alkaloids and lignans [8,9]. The existence of flavones, flavonols and flavonones, free aglycones, their derivatives and glycosides has been proven $[8,10,11]$. The best-known and researched compounds in Cirsium are the flavonoids, which are found in all plant organs. Acacetin, apigenin, cirsimaritin, luteolin, quercetin, pectolinarigenin and their glycosides are among the most common flavonoids $[4,6]$.

Given the notable amount of data on the traditional medicinal usage and therapeutic properties attributed to the Cirsium species, it is necessary to scientifically bioprospect poorly studied species belonging to this genus, such as Cirsium appendiculatum Griseb. (Balkan thistle) against significant human diseases such as diabetes, Alzheimer's disease, atherosclerosis, etc. C. appendiculatum is an herbaceous perennial plant, up to $180 \mathrm{~cm}$ height, flowering from June to September. It is a Balkan endemic plant occurring in Turkey, Greece, Albania, North Macedonia, Serbia and Montenegro [12]. The species is distributed in the alpine zone at altitudes between 1000-2500 m asl and occurs in a wide range of open habitats such as meadows, forests and rivers [12].

An investigation of its health-promoting effects and applications in a variety of nutraceutical, pharmaceutical, medicinal and cosmetic areas represents interest, and the data will complete knowledge of the genus. Accordingly, a wide range of biological activities such as antioxidant activity and inhibitory effects against different enzyme classes were investigated.

In line with the new paradigm in pharmacognosy to obtain massive metabolite profiling of natural extracts for a rational prioritization of bioactive natural products [13], the present study was designed to investigate, for the first time, the phytochemical profile and biological activity of C. appendiculatum extracts. An innovative/efficient workflow based on the association of both UHPLC-HRMS and biochemometrics, using a combination of multiple statistical models (partial least-square discriminant and heat-map analyses) to target bioactive compounds from extracts was developed. 


\section{Results and Discussion}

The complete workflow combining UHPLC-HRMS with discriminant analysis of the chromatographic data and the biological potential is presented on Figure 1.

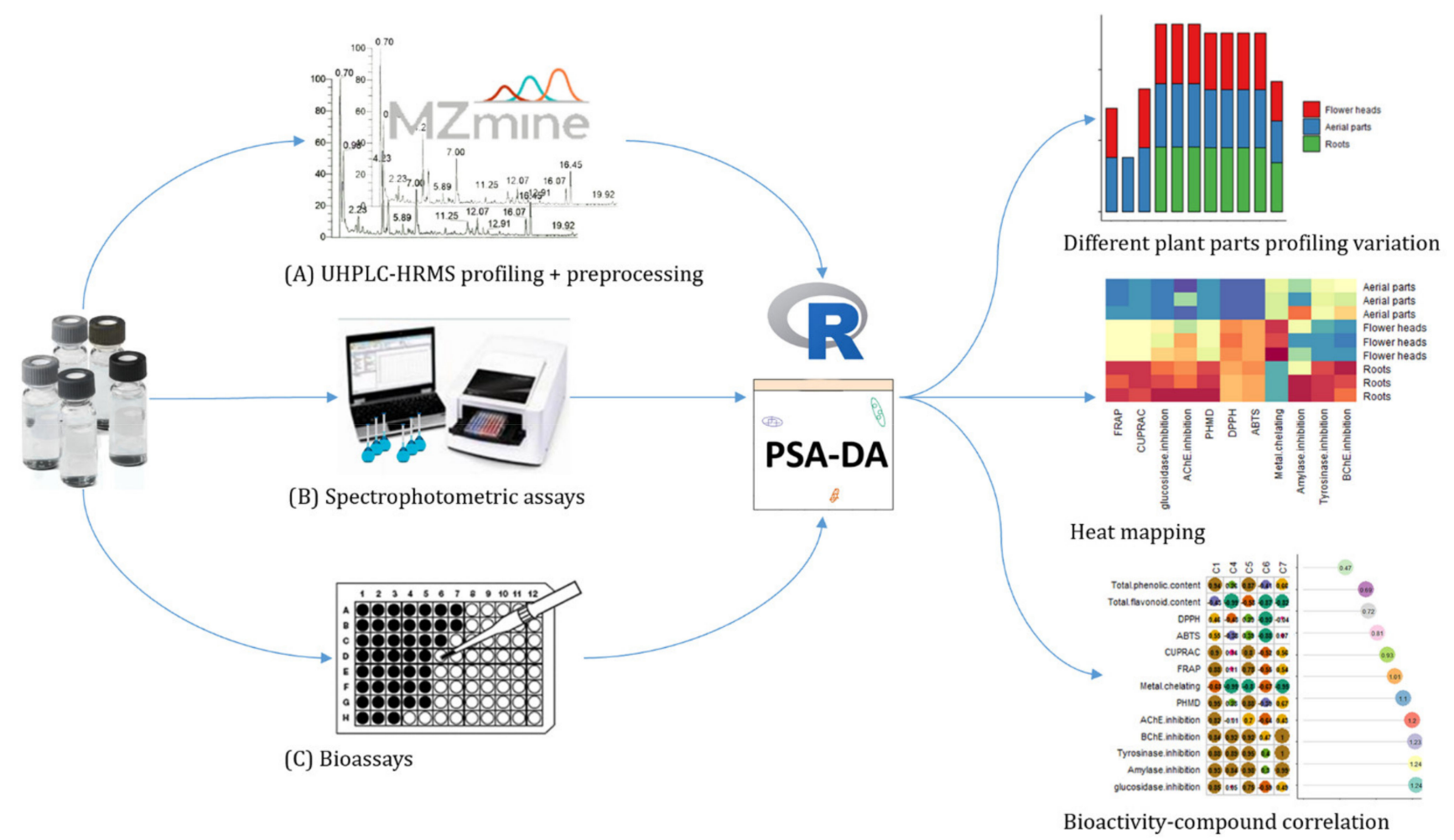

Figure 1. The complete workflow for the biochemometric approach. Samples (flower heads, aerial parts and root extracts) prepared at the same concentration are first injected into UHPLC-HRMS (A). Data are acquired using the data-dependent acquisition mode, then converted through MZmine 2 software processing. In parallel, spectrophotometric assays (B) and bioassays (C) are conducted to determine total phenolic and flavonoid contents and activity and information are tabulated. The final .csv files are then used for the generation of the biochemometic data by partial least-square discriminant analysis (PLS-DA) with R software. Finally, bioactivity mapping was performed.

\subsection{UHPLC-HRMS Profiling of Specialized Natural Products in Cirsium appendiculatum Extracts}

Based on retention times, MS and MS/MS accurate masses and relative ion abundance, elemental composition, fragmentation patterns in MS/MS spectra, conformity to the simulated monoisotopic profiles and comparison with reference standards and literature data, a total of 61 specialized natural products were identified or tentatively annotated in $C$. appendiculatum extracts (Table 1). The total ion chromatograms (TIC) of the studied extracts are depicted in Figure 2.

In the biochemometric approach, peak areas (log (peak area)) for a data quantitative analysis were used. A designed graph clearly shows the differences of the phytochemical components' distribution in the studied herbal extracts (Figure S1). Thus, flower heads contained more flavonoids compared to aerial parts and roots. Subsequently, a qualitative analysis was carried out. 
Table 1. Specialized natural products in Cirsium appendiculatum extracts.

\begin{tabular}{|c|c|c|c|c|c|c|c|}
\hline № & $\begin{array}{l}\text { Identified/Tentatively Annotated } \\
\text { Compound }\end{array}$ & $\begin{array}{l}\text { Molecular } \\
\text { Formula }\end{array}$ & $\begin{array}{l}\text { Exact Mass } \\
{[\mathrm{M}-\mathrm{H}]^{-}}\end{array}$ & $\begin{array}{c}\mathbf{t}_{\mathrm{R}} \\
\text { (Min) }\end{array}$ & $\Delta$ ppm & Distribution & $\begin{array}{c}\text { Level of } \\
\text { Identification } \\
\text { (CAWG) }\end{array}$ \\
\hline \multicolumn{8}{|c|}{ Carboxylic (including hydroxybenzoic and hydroxycinnamic) acids } \\
\hline 1. & protocatechuic acid $^{\mathrm{a}}$ & $\mathrm{C}_{7} \mathrm{H}_{6} \mathrm{O}_{4}$ & 153.0179 & 2.15 & -7.986 & 1,2 & 1 \\
\hline 2. & dihydroxybenzoic acid & $\mathrm{C}_{7} \mathrm{H}_{6} \mathrm{O}_{4}$ & 153.0181 & 3.44 & -8.182 & 2,3 & 2 \\
\hline 3. & gentisic acid $^{a}$ & $\mathrm{C}_{7} \mathrm{H}_{6} \mathrm{O}_{4}$ & 153.0179 & 3.86 & -9.685 & 2 & 1 \\
\hline 4. & vanillic acid $^{\mathrm{a}}$ & $\mathrm{C}_{8} \mathrm{H}_{8} \mathrm{O}_{4}$ & 167.0338 & 4.77 & -6.837 & $1,2,3$ & 1 \\
\hline 5. & 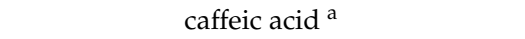 & $\mathrm{C}_{9} \mathrm{H}_{8} \mathrm{O}_{4}$ & 179.0340 & 3.51 & -5.317 & $1,2,3$ & 1 \\
\hline 6. & quinic acid & $\mathrm{C}_{7} \mathrm{H}_{12} \mathrm{O}_{6}$ & 191.0551 & 3.18 & -5.032 & $1,2,3$ & 2 \\
\hline 7. & eucomic acid & $\mathrm{C}_{11} \mathrm{H}_{12} \mathrm{O}_{6}$ & 239.0557 & 3.38 & -0.717 & $1,2,3$ & 2 \\
\hline 8. & caffeoyl-syringic acid & $\mathrm{C}_{18} \mathrm{H}_{16} \mathrm{O}_{8}$ & 359.0985 & 2.32 & 0.390 & $1,2,3$ & 4 \\
\hline \multicolumn{8}{|c|}{ Hydroxybenzoic and hydroxycinnamc acids glycosides } \\
\hline 9. & $\begin{array}{c}\text { 4-hydroxyphenylacetic acid } \\
\text { O- } \beta \text {-D-glucoside }\end{array}$ & $\mathrm{C}_{14} \mathrm{H}_{18} \mathrm{O}_{8}$ & 313.0933 & 2.18 & 1.467 & 2 & 2 \\
\hline 10. & vanillic acid $O$-deoxyhexoside & $\mathrm{C}_{14} \mathrm{H}_{18} \mathrm{O}_{8}$ & 313.0934 & 3.25 & 1.467 & 2,3 & 2 \\
\hline 11. & gentisic acid $O$-hexoside & $\mathrm{C}_{14} \mathrm{H}_{20} \mathrm{O}_{8}$ & 315.1087 & 1.92 & 0.601 & $1,2,3$ & 2 \\
\hline 12. & $p$-hydroxybenzoic acid $O$-hexoside & $\mathrm{C}_{14} \mathrm{H}_{20} \mathrm{O}_{8}$ & 315.1086 & 2.10 & 0.029 & $1,2,3$ & 2 \\
\hline 13. & vanillic acid $O$-hexoside & $\mathrm{C}_{14} \mathrm{H}_{18} \mathrm{O}_{9}$ & 329.0885 & 1.71 & 2.020 & $1,2,3$ & 2 \\
\hline 14. & leonuriside $\mathrm{A}$ & $\mathrm{C}_{14} \mathrm{H}_{20} \mathrm{O}_{9}$ & 331.1037 & 1.44 & 0.739 & $1,2,3$ & 2 \\
\hline 15. & gallic acid $O$-hexoside & $\mathrm{C}_{13} \mathrm{H}_{16} \mathrm{O}_{10}$ & 331.0676 & 1.58 & 1.601 & 2 & 2 \\
\hline \multicolumn{8}{|c|}{ Acylquinic acids } \\
\hline 16. & 1-p-coumaroylquinic acid & $\mathrm{C}_{16} \mathrm{H}_{18} \mathrm{O}_{8}$ & 337.0932 & 4.61 & 1.007 & 1,2 & 2 \\
\hline 17. & 3-p-coumaroylquinic acid & $\mathrm{C}_{16} \mathrm{H}_{18} \mathrm{O}_{8}$ & 337.0935 & 3.01 & 1.748 & 2 & 2 \\
\hline 18. & 1-caffeoylquinic acid & $\mathrm{C}_{16} \mathrm{H}_{18} \mathrm{O}_{9}$ & 353.0880 & 2.27 & 0.410 & 1,2 & 2 \\
\hline 19. & neochlorogenic (3-caffeoylquinic) acid & $\mathrm{C}_{16} \mathrm{H}_{18} \mathrm{O}_{9}$ & 353.0878 & 3.21 & -0.015 & $1,2,3$ & 1 \\
\hline 20. & chlorogenic (5-caffeoylquinic) acid ${ }^{a}$ & $\mathrm{C}_{16} \mathrm{H}_{18} \mathrm{O}_{9}$ & 353.0874 & 3.94 & -1.233 & $1,2,3$ & 1 \\
\hline 21. & 4-caffeoylquinic acid & $\mathrm{C}_{16} \mathrm{H}_{18} \mathrm{O}_{9}$ & 353.0879 & 6.27 & 0.155 & $1,2,3$ & 2 \\
\hline 22. & 3,4-dicaffeoylquinic acid ${ }^{\mathrm{a}}$ & $\mathrm{C}_{25} \mathrm{H}_{24} \mathrm{O}_{12}$ & 515.1199 & 5.73 & 0.836 & $1,2,3$ & 1 \\
\hline 23. & 1,5-dicaffeoylquinic acid ${ }^{\text {a }}$ & $\mathrm{C}_{25} \mathrm{H}_{24} \mathrm{O}_{12}$ & 515.1191 & 5.91 & -0.697 & $1,2,3$ & 1 \\
\hline 24. & 3,5-dicaffeoylquinic acid & $\mathrm{C}_{25} \mathrm{H}_{24} \mathrm{O}_{12}$ & 515.1199 & 6.08 & 0.720 & $1,2,3$ & 1 \\
\hline 25. & 4,5-dicaffeoylquinic acid & $\mathrm{C}_{25} \mathrm{H}_{24} \mathrm{O}_{12}$ & 515.1191 & 6.25 & -0.697 & $1,2,3$ & 1 \\
\hline 26. & 1,3,5-tricaffeoylquinic acid & $\mathrm{C}_{34} \mathrm{H}_{30} \mathrm{O}_{15}$ & 677.1512 & 5.15 & - & $1,2,3$ & 1 \\
\hline \multicolumn{8}{|c|}{ Flavonoids } \\
\hline 27. & apigenin $^{a}$ & $\mathrm{C}_{15} \mathrm{H}_{9} \mathrm{O}_{5}$ & 269.0459 & 8.58 & 1.313 & 1,3 & 1 \\
\hline 28. & genkwanin $^{a}$ & $\mathrm{C}_{16} \mathrm{H}_{12} \mathrm{O}_{5}$ & 283.0608 & 11.41 & -1.543 & 2 & 1 \\
\hline 29. & acacetin & $\mathrm{C}_{16} \mathrm{H}_{12} \mathrm{O}_{5}$ & 283.0615 & 11.40 & 1.142 & 1,3 & 2 \\
\hline 30. & luteolin $^{\mathrm{a}}$ & $\mathrm{C}_{15} \mathrm{H}_{10} \mathrm{O}_{6}$ & 285.0404 & 7.55 & -0.075 & 1,3 & 1 \\
\hline 31. & hispidulin (scutellarein-6-methyl ether) $^{\text {a }}$ & $\mathrm{C}_{16} \mathrm{H}_{12} \mathrm{O}_{6}$ & 299.0561 & 8.81 & -0.172 & $1,2,3$ & 1 \\
\hline 32. & diosmetin & $\mathrm{C}_{16} \mathrm{H}_{12} \mathrm{O}_{6}$ & 299.0560 & 9.28 & -0.272 & 1 & 1 \\
\hline 33. & quercetin $^{\mathrm{a}}$ & $\mathrm{C}_{15} \mathrm{H}_{9} \mathrm{O}_{6}$ & 301.0354 & 7.61 & 1.11 & 1 & 1 \\
\hline 34. & pectolinarigenin & $\mathrm{C}_{17} \mathrm{H}_{14} \mathrm{O}_{6}$ & 313.0722 & 12.26 & 1.305 & $1,2,3$ & 2 \\
\hline 35. & nepetin (6-methoxyluteolin) & $\mathrm{C}_{16} \mathrm{H}_{11} \mathrm{O}_{7}$ & 315.0514 & 8.09 & 1.251 & 1,3 & 2 \\
\hline 36. & cirsiliol & $\mathrm{C}_{17} \mathrm{H}_{14} \mathrm{O}_{7}$ & 329.0669 & 8.87 & 0.772 & 1 & 2 \\
\hline 37. & apigenin 7-O-glucoside ${ }^{a}$ & $\mathrm{C}_{21} \mathrm{H}_{20} \mathrm{O}_{10}$ & 431.0988 & 6.06 & 0.835 & 1 & 1 \\
\hline 38. & kaempferol 3-O-deoxyhexoside & $\mathrm{C}_{21} \mathrm{H}_{20} \mathrm{O}_{10}$ & 431.0983 & 6.60 & -0.232 & 1,2 & 2 \\
\hline 39. & apigenin $O$-hexuronide & $\mathrm{C}_{21} \mathrm{H}_{18} \mathrm{O}_{11}$ & 445.0770 & 6.45 & -0.347 & $1,2,3$ & 2 \\
\hline 40. & kaempferol 3-O-glucoside ${ }^{a}$ & $\mathrm{C}_{21} \mathrm{H}_{20} \mathrm{O}_{11}$ & 447.0935 & 5.63 & 0.571 & 1,2 & 1 \\
\hline 41. & luteolin 7-O-glucoside ${ }^{a}$ & $\mathrm{C}_{21} \mathrm{H}_{19} \mathrm{O}_{11}$ & 447.0934 & 6.04 & 0.281 & $1,2,3$ & 1 \\
\hline 42. & luteolin 7-O-hexuronide & $\mathrm{C}_{21} \mathrm{H}_{18} \mathrm{O}_{12}$ & 461.0734 & 5.37 & 1.911 & 1,3 & 2 \\
\hline 43. & diosmetin 7-O-hexoside & $\mathrm{C}_{22} \mathrm{H}_{22} \mathrm{O}_{11}$ & 461.1092 & 6.30 & 0.684 & $1,2,3$ & 2 \\
\hline 44. & hispidulin 7-O-hexoside & $\mathrm{C}_{22} \mathrm{H}_{22} \mathrm{O}_{11}$ & 461.1093 & 6.67 & 0.966 & $1,2,3$ & 2 \\
\hline 45. & hispidulin-O-hexuronide & $\mathrm{C}_{22} \mathrm{H}_{20} \mathrm{O}_{12}$ & 475.0882 & 6.33 & 0.002 & 1,3 & 2 \\
\hline 46. & pectolinarigenin-O-hexoside & $\mathrm{C}_{23} \mathrm{H}_{24} \mathrm{O}_{11}$ & 475.1247 & 8.11 & 0.159 & 1 & 2 \\
\hline 47. & nepetin-O-hexoside & $\mathrm{C}_{22} \mathrm{H}_{21} \mathrm{O}_{12}$ & 477.1040 & 5.65 & 0.316 & 1,3 & 2 \\
\hline 48. & nepetin-O-hexuronide & $\mathrm{C}_{22} \mathrm{H}_{20} \mathrm{O}_{13}$ & 491.0835 & 6.32 & 0.725 & 1 & 2 \\
\hline 49. & acaciin (acacetin 7-O-rutinoside) ${ }^{a}$ & $\mathrm{C}_{28} \mathrm{H}_{32} \mathrm{O}_{14}$ & 591.1730 & 7.59 & 3.622 & $1,2,3$ & 1 \\
\hline 50. & kaempferol 3-O-rutinoside ${ }^{a}$ & $\mathrm{C}_{27} \mathrm{H}_{30} \mathrm{O}_{15}$ & 593.1532 & 5.40 & 3.383 & 1,3 & 1 \\
\hline 51. & hispidulin 7-O-rutinoside & $\mathrm{C}_{28} \mathrm{H}_{32} \mathrm{O}_{15}$ & 607.1675 & 6.34 & 1.049 & $1,2,3$ & 2 \\
\hline 52. & $\begin{array}{l}\text { pectolinarin (pectolinarigenin }^{\text {7-O- rutinoside) }}{ }^{\mathrm{a}}\end{array}$ & $\mathrm{C}_{29} \mathrm{H}_{34} \mathrm{O}_{15}$ & 621.1824 & 7.67 & -0.199 & $1,2,3$ & 1 \\
\hline
\end{tabular}


Table 1. Cont.

\begin{tabular}{|c|c|c|c|c|c|c|c|}
\hline № & $\begin{array}{l}\text { Identified/Tentatively Annotated } \\
\text { Compound }\end{array}$ & $\begin{array}{l}\text { Molecular } \\
\text { Formula }\end{array}$ & $\begin{array}{l}\text { Exact Mass } \\
{[\mathrm{M}-\mathrm{H}]^{-}}\end{array}$ & $\begin{array}{c}\mathbf{t}_{\mathrm{R}} \\
(\mathrm{Min})\end{array}$ & $\Delta$ ppm & Distribution & $\begin{array}{l}\text { Level of } \\
\text { Identification } \\
\text { (CAWG) }\end{array}$ \\
\hline \multicolumn{8}{|c|}{ Free fatty acids } \\
\hline 53. & nonanedioic acid (azelaic acid) & $\mathrm{C}_{9} \mathrm{H}_{16} \mathrm{O}_{4}$ & 187.0967 & 6.32 & -4.502 & $1,2,3$ & 2 \\
\hline 54. & 3-hydroxysuberic acid & $\mathrm{C}_{8} \mathrm{H}_{14} \mathrm{O}_{5}$ & 189.0758 & 4.64 & -5.483 & $1,2,3$ & 2 \\
\hline 55. & 3-hydroxyazelaic acid & $\mathrm{C}_{9} \mathrm{H}_{16} \mathrm{O}_{5}$ & 203.0918 & 6.25 & -3.677 & $1,2,3$ & 2 \\
\hline 56. & 2-dodecenoic acid & $\mathrm{C}_{12} \mathrm{H}_{20} \mathrm{O}_{4}$ & 227.1287 & 9.46 & -0.715 & 2,3 & 2 \\
\hline 57. & 9,13-dyhidroxyoctadeca-9,11,13-trienoic acid & $\mathrm{C}_{18} \mathrm{H}_{30} \mathrm{O}_{4}$ & 309.2074 & 12.76 & 0.768 & 2,3 & 2 \\
\hline 58. & 11,12-dyhidroxyoctadeca-9,13,15-trienoic acid & $\mathrm{C}_{18} \mathrm{H}_{30} \mathrm{O}_{4}$ & 309.2075 & 12.91 & -0.332 & 2 & 2 \\
\hline 59. & 9,10-dyhidroxyoctadeca-12,14,16-trienoic acid & $\mathrm{C}_{18} \mathrm{H}_{30} \mathrm{O}_{4}$ & 309.2074 & 10.81 & 1.835 & 2 & 2 \\
\hline 60. & 9,13-dyhidroxyoctadeca-11,13-dienoic acid & $\mathrm{C}_{18} \mathrm{H}_{32} \mathrm{O}_{4}$ & 311.2231 & 13.67 & 0.859 & $1,2,3$ & 2 \\
\hline 61. & 9,10-dyhidroxyoctadeca-9-enoic acid & $\mathrm{C}_{18} \mathrm{H}_{34} \mathrm{O}_{4}$ & 313.2388 & 13.79 & 0.885 & 3 & 2 \\
\hline
\end{tabular}

${ }^{\text {a }}$ Compare to reference standards. 1-flower heads; 2-aerial parts; 3-roots.

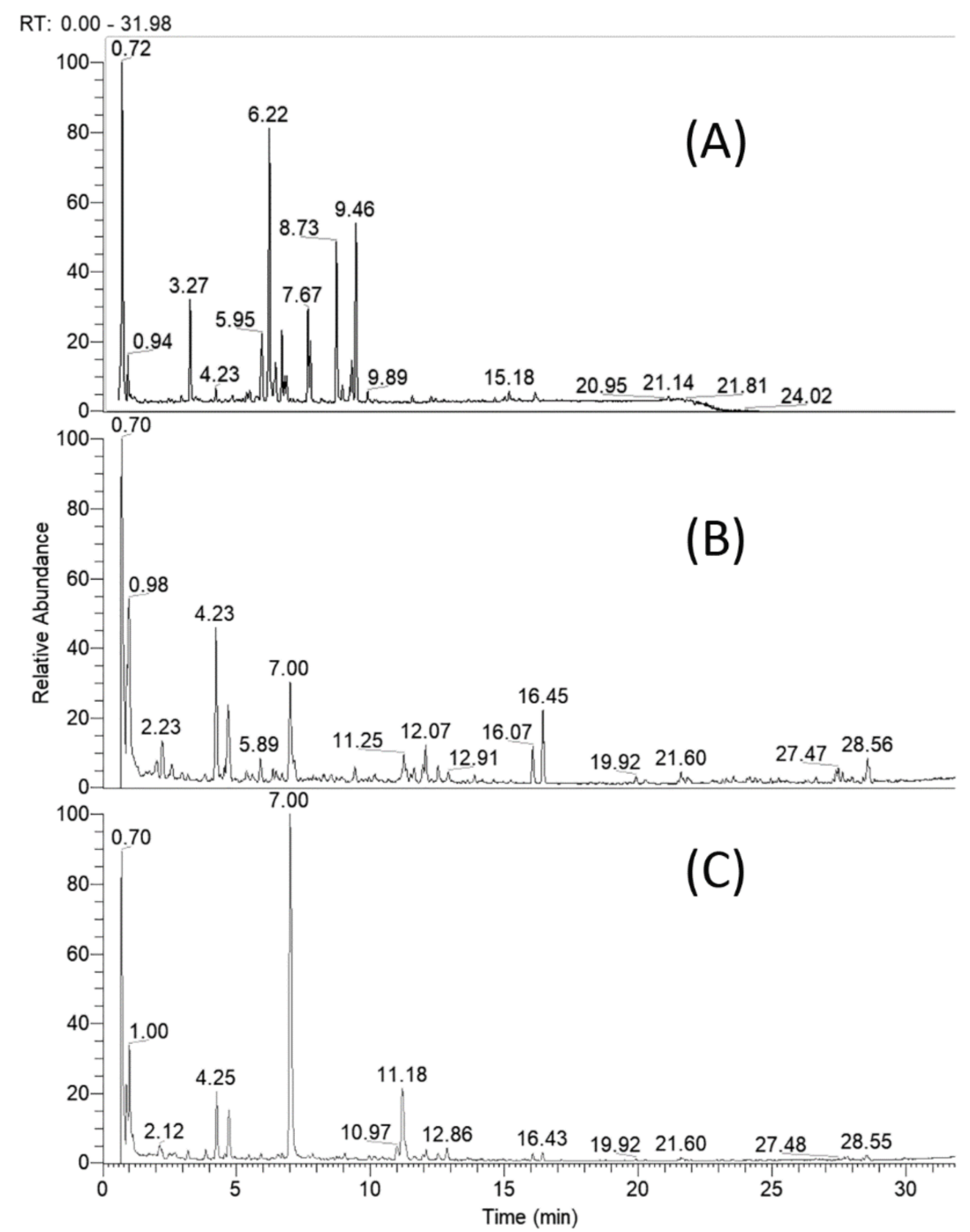

Figure 2. Total ion chromatogram of Cirsium appendiculatum extracts; (A) flower heads, (B) aerial parts, (C) roots.

2.1.1. Carboxylic (Including Hydroxybenzoic, Hydroxycinnamic and Acylquinic) Acids and Their Glycosides

Hydroxybenzoic (1-4) and hydroxycinnamic acids (5 and 8), their glycosides (9-15) and quinic acid (6) were identified based on a comparison with reference standards 
and literature data (Tables 1 and S1). The tentative structure of compound 8 was deduced from fragment observation at $\mathrm{m} / \mathrm{z} 197.045$ [syringic acid- $\mathrm{H}]^{-}$and 123.007 [syringic acid-H- $\left.-\mathrm{CO}_{2}-2 \mathrm{CH}_{3}\right]^{-}$, referring to the elimination of caffeoyl moiety $(-162.05 \mathrm{Da})$ and eased its preliminary assignment as caffeoyl-syringic acid [2]. The MS/MS spectrum of 10 revealed a neutral loss of deoxyhexose $(-146.09 \mathrm{Da})$, and diagnostic fragment ions for vanillic acid at $\mathrm{m} / \mathrm{z} 167.034$ [vanillic acid-H] ${ }^{-}, 152.010$ [vanillic acid- $\left.\mathrm{H}-\mathrm{CH}_{3}\right]^{-}$and 123.043 [vanillic acid- $\left.\mathrm{H}-\mathrm{CO}_{2}\right]^{-}$, and were tentatively ascribed to vanillic acid $\mathrm{O}$-deoxyhexoside (Tables 1 and S1) [14]. In the same manner compounds 7 [15], 8 [16], 11 [17], 12 [18], 14 [19] and 15 [20] were tentatively annotated (Tables 1 and S1). The isolation of 8 was not reported in the literature and therefore it could be referred to as "unknown".

The acylquinic acid dereplication was based on conformity with the structure-diagnostic hierarchical keys for chlorogenic acid identification proposed by Clifford et al. [21] and later developed by Jaiswal et al. [22], as well as literature data acquired by hybrid Q-Orbitrap mass spectrometry [2]. Thus, six mono-acylquinic (16-21), four di-acylquinic (22-25) and one tri-acylquinic (26) acids was annotated in the studied extracts.

\subsubsection{Flavonoids, Flavones and Flavonols}

The aglycones apigenin (27), luteolin (30) and quercetin (33) were deduced from the Retro-Diels-Alder (RDA) cleavages ${ }^{1,3} \mathrm{~A}^{-}$at $m / z 151.002,{ }^{1,3} \mathrm{~B}^{-}$at $\mathrm{m} / \mathrm{z} 117.033$ (27) and $133.028(30),{ }^{0,4} \mathrm{~A}^{-}$at $m / z 107.012,{ }^{1,2} \mathrm{~A}^{-}$at $m / z 178.998(33)$ and ${ }^{1,2} \mathrm{~B}^{-}$at $\mathrm{m} / \mathrm{z} 121.028$ (33) (Tables 1 and S1) [2]. The fragmentation pathways of 38, 40 and 50 showed neutral mass losses of deoxyhexose (146.059 Da), hexose (162.053 Da) and rutinose (308.112 Da). Consequently, the aglycone was registered at $m / z 285.041$ together with the radical aglycone at $m / z 284.033$ [Y-H- $^{-\bullet}$, as usually seen in flavonoids substituted at the 3-position, i.e., flavonol 3-O-glycosides. Fragment ions at $m / z 255.030$ and 227.035 resulting from neutral losses of $\mathrm{CH}_{2} \mathrm{O}$ and $\mathrm{CO}$, respectively, being present in high abundance corroborated kaempferol [2]. MS/MS spectra of 39 and 42 demonstrated neutral mass losses of hexuronic acid (176.033 Da) together with base peaks at $m / z 269.045$ and 285.0403. Accordingly, 39 and 42 could be associated with apigenin $O$-hexuronide and luteolin $O$-hexuronide. Compounds 27, 30, 37, 40 and 41 were unambiguously identified by a comparison with retention times in LC-MS and fragmentation fingerprints of the reference standards.

\subsubsection{Methoxylated Flavonoids}

MS/MS spectrum of 34 revealed fragment ions at $m / z 298.048\left[\mathrm{M}-\mathrm{H}-\bullet \mathrm{CH}_{3}\right]^{-}$and 283.025 $\left[\mathrm{M}-\mathrm{H}-2 \bullet \mathrm{CH}_{3}\right]^{-}$, indicating a subsequent loss of two methyl radicals. A series of fragment ions resulting from neutral losses were registered at $m / z 255.029\left[\mathrm{M}-\mathrm{H}-2 \bullet \mathrm{CH}_{3}-\mathrm{CO}\right]^{-}, 227.034$

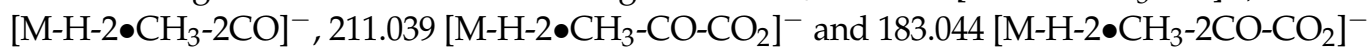
(Tables 1 and S1). A methoxy group at C-6 (ring A) and another one in ring $\mathrm{B}$ were deduced from the lack of the initial RDA ions ${ }^{1,3} \mathrm{~A}^{-}$(181.014) and ${ }^{1,3} \mathrm{~B}^{-}$(147.045). In addition, the neutral losses of $16 \mathrm{Da}\left(\mathrm{CH}_{4}\right), 14 \mathrm{Da}\left(\mathrm{CH}_{2}\right)$ and $28 \mathrm{Da}(\mathrm{CO})$ afford fragment ions in the low mass range at $m / z 136.988\left({ }^{1,3} \mathrm{~A}^{-}-\mathrm{CH}_{4}-\mathrm{CO}\right)$ and $m / z 117.028\left({ }^{1,3} \mathrm{~B}^{-}-\mathrm{CH}_{2}\right)($ Tables 1 and $\mathrm{S} 1$, Figure 3). 


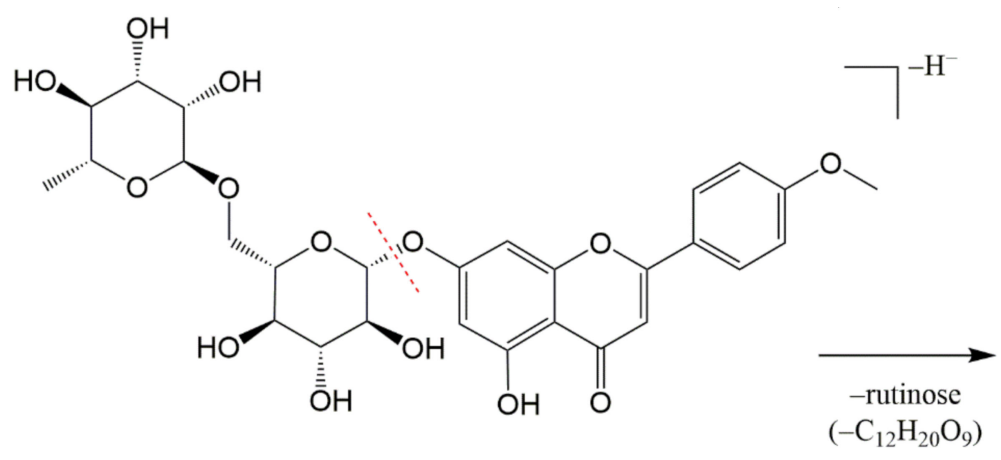<smiles>CC(C)Oc1ccc(-c2cc(=O)c3c(O)cc(O)cc3o2)cc1</smiles>

Acaciin

Chemical Formula: $\mathrm{C}_{28} \mathrm{H}_{31} \mathrm{O}_{14}$ $\mathrm{m} / \mathrm{z}: 591.1719$<smiles>C[IH+]CC(=O)C1C(=O)C=C(O)C=C1O</smiles>

Chemical Formula: $\mathrm{C}_{16} \mathrm{H}_{11} \mathrm{O}_{5}$ $\mathrm{m} / \mathrm{z}: 283.0612$<smiles>CC(C)(C)C</smiles>

Chemical Formula: $\mathrm{C}_{7} \mathrm{H}_{3} \mathrm{O}_{4}$ m/z: 151.0037<smiles>[O-]c1cc#cc(O)c1</smiles>

Chemical Formula: $\mathrm{C}_{6} \mathrm{H}_{3} \mathrm{O}_{2}{ }^{-}$ m/z: 107.0139<smiles>CC(C)Oc1ccc(-c2cc3c(O)cc(O)cc3o2)cc1</smiles>

Chemical Formula: $\mathrm{C}_{15} \mathrm{H}_{8} \mathrm{O}_{5}{ }^{-}$ $\mathrm{m} / \mathrm{z}: 268.0377$

Chemical Formula: $\mathrm{C}_{14} \mathrm{H}_{8} \mathrm{O}_{4}{ }^{--}$ m/z: 240.0428

Figure 3. Fragmentation pathway of acaciin (49).

These data corresponded to the Justesen key for methoxylated flavonoid dereplication [23] and the detailed analysis of the fragmentation pathway of methoxylated flavonoids done by Ren et al. [24]. Thus, 34 was identified as pectolinarigenin (Table 1). By analogy with 34,35 gave fragment ions at $m / z 136.986\left({ }^{1,3} \mathrm{~A}^{-}-\mathrm{CH}_{2}-\mathrm{H}_{2} \mathrm{O}-\mathrm{CO}\right)$ and ${ }^{1,3} \mathrm{~B}^{-}$at $\mathrm{m} / \mathrm{z} 133.028$, indicating a methoxyl group in the A ring. Compound 35 was ascribed to nepetin, previously isolated from Cirsium species [8]. The isobaric pair 28/29 afforded $[\mathrm{M}-\mathrm{H}]^{-}$at $\mathrm{m} / \mathrm{z} 283.061$ and fragment ions at $\mathrm{m} / \mathrm{z} 268.037\left[\mathrm{M}-\mathrm{H}-\bullet \mathrm{CH}_{3}\right], 240.043\left[\mathrm{M}-\mathrm{H}-\bullet \mathrm{CH}_{3}-\right.$ $\mathrm{CO}]^{-}$and $239.034\left[\mathrm{M}-\mathrm{H}-\mathrm{CO}_{2}\right]^{-}$, indicating methoxylated flavonoids. A free hydroxyl group in the $\mathbf{B}$ ring of 28 was deduced from the RDA fragment ion at $m / z 117.033\left({ }^{1,3} \mathrm{~B}^{-}\right)$, while a diagnostic ion at $m / z 165.349\left(\left(^{1,3} \mathrm{~A}^{-}\right)\right.$, corresponding to the methoxyl group, was deduced in the A ring. These data are consisted with Justesen [23] and 28/29 were ascribed to genkwanin ( $4^{\prime}, 5$-dihydroxy-7-methoxyflavon) and acacetin (5,7-dihydroxy-4 $4^{\prime}$ methoxyflavon), respectively (Tables 1 and $\mathrm{S} 1$ ).

Two peaks (31 and 32) produced the same $[\mathrm{M}-\mathrm{H}]^{-}$at $\mathrm{m} / \mathrm{z} 299.056$ and a fragment ion at $\mathrm{m} / \mathrm{z} 284.032\left[\mathrm{M}-\mathrm{H}-\bullet \mathrm{CH}_{3}\right]^{-}$(Tables 1 and S1). Compound 32 gave diagnostic ions 
at $m / z 256.035\left[\mathrm{M}-\mathrm{H}-\bullet \mathrm{CH}_{3}-\mathrm{CO}\right]^{-}, 151.002\left({ }^{1,3} \mathrm{~A}^{-}\right)$and $107.012\left({ }^{0,4} \mathrm{~A}^{-}\right)$, indicating that the methoxy group is situated in the $\mathrm{B}$ ring. Compound 31 yielded a relevant fragment ion at $\mathrm{m} / \mathrm{z} 136.988\left({ }^{1,3} \mathrm{~A}^{-}-\mathrm{CH}_{4}-\mathrm{CO}\right)$, corresponding to a methoxyl group at $\mathrm{C}-6$ in the A-ring. Thus, 31 and 32 could be related to hispidulin and diosmetin, respectively (Tables 1 and S1) [23]. In the same manner, 36 afforded diagnostic ions at $\mathrm{m} / \mathrm{z}$ $314.043\left[\mathrm{M}-\mathrm{H}-\bullet \mathrm{CH}_{3}\right]^{-}, 299.019\left[\mathrm{M}-\mathrm{H}-2 \bullet \mathrm{CH}_{3}\right]^{-}, 271.025\left[\mathrm{M}-\mathrm{H}-2 \bullet \mathrm{CH}_{3}-\mathrm{CO}\right]^{-}$and 227.035 $\left[\mathrm{M}-\mathrm{H}-2 \bullet \mathrm{CH}_{3}-\mathrm{CO}-\mathrm{CO}_{2}\right]^{-}$together with RDA fragments at $\mathrm{m} / \mathrm{z} 161.023\left[{ }^{1,3} \mathrm{~A}^{-}-\mathrm{CH}_{4}-\mathrm{H}_{2} \mathrm{O}\right]^{-}$ and $151.002\left[{ }^{1,3} \mathrm{~A}^{-}-\mathrm{CH}_{4}-\mathrm{CO}\right]$. Accordingly, 36 could be associated with cirsiliol, previously determined in Cirsium species [8].

By analogy to flavones and flavonols, the glycosides of methoxylated flavonoids $43-49$ and 51-52 were ascribed. MS/MS spectra of 49 and 52 revealed base peaks corresponding to the simultaneous loss of hexose and deoxyhexose. The aglycone of 49 showed a fragmentation pathway similar to acacetin (29) [23], while 52 corresponded to pectolinarigenin (34). Thus, 49 and 52 were identified as rutinosides acaciin and pectolinarin, respectively. The identification of 31, 49 and 52 was confirmed by comparison with reference standards (Tables 1 and S1).

\subsubsection{Free Fatty Acids}

In (-) ESI-MS/MS of $53\left(\mathrm{C}_{9} \mathrm{H}_{16} \mathrm{O}_{4}\right),[\mathrm{M}-\mathrm{H}]^{-}$at $\mathrm{m} / \mathrm{z} 187.096$, the subsequent and concomitant losses of $\mathrm{H}_{2} \mathrm{O}(-18)$ and $\mathrm{CO}_{2}(-44)$ yielded several characteristic ions at $m / z 166.990\left[\mathrm{M}-\mathrm{H}-\mathrm{H}_{2} \mathrm{O}\right]-, m / z 143.106\left[\mathrm{M}-\mathrm{H}-\mathrm{CO}_{2}\right]^{-}$and $97.064\left[\mathrm{M}-\mathrm{H}-2 \mathrm{CO}_{2}\right]^{-}$, and a base peak at $m / z 125.095\left(\left[\mathrm{M}-\mathrm{H}-\mathrm{CO}_{2}-\mathrm{H}_{2} \mathrm{O}\right]^{-}\right.$. Based on comparison with the literature data, 53 could be related to the saturated dicarboxylic acid-nonanedioic acid (azelaic acid) [25] (Tables 1 and S1). Compound 55 demonstrated a similar fragmentation pathway. However, 55 gave fragment ions at $m / z 143.070\left[\mathrm{C}_{7} \mathrm{H}_{11} \mathrm{O}_{3}\right]^{-}, 113.095\left[\mathrm{C}_{7} \mathrm{H}_{13} \mathrm{O}\right]^{-}$and $59.012\left[\mathrm{C}_{2} \mathrm{H}_{3} \mathrm{O}_{2}\right]^{-}$, corresponding to a presence of the hydroxyl group at $\mathrm{C}-3$. Thus, 55 was ascribed to 3-hydroxylazelaic acid (Tables 1 and S1). Compound 54 differs from 55 by one $\mathrm{CH}_{2}$ group and was tentatively identified as 3-hydroxyoctandioic acid (3-hydroxysuberic acid) (Tables 1 and S1). Based on a comparison between metabolites' AUC, compound 54 was found to be the major compound in $\mathrm{C}$. appendiculatum roots.

In the (-) ESI-MS/MS spectrum of $56\left(\mathrm{C}_{12} \mathrm{H}_{20} \mathrm{O}_{4}\right)$, a base peak at $m / z 183.138\left[\mathrm{M}-\mathrm{H}-\mathrm{CO}_{2}\right]^{-}$ and a fragment ion at $m / z 165.127\left(\mathrm{C}_{11} \mathrm{H}_{17} \mathrm{O}\right)$ indicated the presence of double bond at $\mathrm{C}-2$. Thus, the compound was identified as dodec-2-endioic acid (traumatic acid). Similarly, 57-61 were identified as polyunsatured fatty acids [26] (Tables 1 and S1).

\subsection{Total Content of Phenolics and Flavonoids}

Polyphenols and their biological properties are one of the most attractive topics in the natural sciences. Nowadays, humanity needs to substitute synthetic compounds with natural ones. This means safe and alternative raw materials need to be found [27]. In this sense, total phenolic and flavonoid content is considered a first insight in evaluating plant extracts. Thus, the total amount of these biocompounds in tested extracts were determined by using spectrophotometric methods (Table 2). Root extract was found to have the highest content of phenolics (143.62 mgGAE/g), followed by flower heads and aerial parts (71.75 $\pm 1.47 \mathrm{mgGAE} / \mathrm{g}$ and $26.02 \pm 1.49 \mathrm{mgGAE} / \mathrm{g}$, respectively).

Regarding total flavonoids, the values are in the following order: flower heads (46.59 mg RE/g) > roots (3.99 mg RE/g) > aerial parts (2.64 mg RE/g). Hence, flavonoids represent about $50 \%$ of the total phenolic components in flower head extract. According to a literature survey, different levels of total bioactive compounds in Cirsium species were observed [28,29]. These differences could be linked to the habitat of the studied plant, climate conditions or extraction procedures/solvents. However, in past years, the utilization of spectrophotometric methods for total content of bioactive compounds has led to some concerns, and these methods are not used by most scientists anymore [30]. Thus, plant matrices are very complexed and phenolics as well as other components such as peptides could be reacting with Folin's reagent. Finally, the exact quantity of bioactive 
constituents has to be confirmed by chromatographic techniques such as LC-MS/MS, NMR and Q-TOF-MS analysis.

Table 2. Total bioactive compounds and antioxidant properties of Cirsium appendiculatum extracts *.

\begin{tabular}{|c|c|c|c|c|c|c|c|c|}
\hline Parts & $\begin{array}{c}\text { Total Phenolic } \\
\text { Content } \\
\text { (mgGAE/g) }\end{array}$ & $\begin{array}{c}\text { Total } \\
\text { Flavonoid } \\
\text { Content } \\
(\mathrm{mgRE} / \mathrm{g})\end{array}$ & $\begin{array}{c}\text { DPPH・ } \\
\text { (mgTE/g) }\end{array}$ & $\begin{array}{c}\text { ABTS } \bullet+ \\
\text { (mgTE/g) }\end{array}$ & $\begin{array}{l}\text { CUPRAC } \\
\text { (mgTE/g) }\end{array}$ & $\begin{array}{c}\text { FRAP } \\
\text { (mg TE/g) }\end{array}$ & $\begin{array}{c}\text { PHMD } \\
\text { (mmolTE/g) }\end{array}$ & $\begin{array}{c}\text { Metal } \\
\text { Chelating } \\
\text { (mgEDTAE/g) }\end{array}$ \\
\hline Flower heads & $71.75 \pm 1.47^{b}$ & $46.59 \pm 0.89^{a}$ & $101.79 \pm 0.15^{a}$ & $224.57 \pm 0.57^{a}$ & $356.97 \underset{\mathrm{b}}{ \pm} 11.52$ & $169.60 \pm 0.84^{b}$ & $1.71 \pm 0.07^{\mathrm{b}}$ & $32.53 \pm 3.51^{a}$ \\
\hline $\begin{array}{l}\text { Aerial parts } \\
\text { Roots }\end{array}$ & $\begin{array}{c}26.02 \pm 1.49^{\mathrm{c}} \\
143.62 \pm 2.99^{\mathrm{a}}\end{array}$ & $\begin{array}{l}2.64 \pm 0.08^{c} \\
3.99 \pm 0.06^{b}\end{array}$ & $\begin{array}{l}70.25 \pm 1.91^{c} \\
97.95 \pm 0.60^{b}\end{array}$ & $\begin{array}{l}124.16 \pm 4.73^{b} \\
224.59 \pm 0.33^{\mathrm{a}}\end{array}$ & $\begin{array}{l}103.77 \pm 5.89^{c} \\
618.36 \pm 5.17^{a}\end{array}$ & $\begin{array}{c}69.98 \pm 2.01^{\mathrm{c}} \\
269.89 \pm 8.50^{\mathrm{a}}\end{array}$ & $\begin{array}{l}0.74 \pm 0.01^{\mathrm{c}} \\
3.36 \pm 0.15^{\mathrm{a}}\end{array}$ & $\begin{array}{c}9.42 \pm 0.54^{b} \\
\text { na }\end{array}$ \\
\hline
\end{tabular}

* Values are expressed as mean \pm S.D ( $n: 3)$. GAE: Gallic acid equivalent; RE: Rutin equivalent; TE: Trolox equivalent; EDTAE: EDTA equivalent; na: not active. Different letters $(\mathrm{a}, \mathrm{b}$ and $\mathrm{c})$ indicate significant differences in the extracts $(p<0.05)$

\subsection{Antioxidant Properties}

In the present study, C. appendiculatum extracts were tested for antioxidant potential (Table 2). $\mathrm{DPPH}^{\bullet}$ and $\mathrm{ABTS}^{\bullet+}$ were used to evaluate radical scavenging ability. The root $\left(97.95 \mathrm{mg} \mathrm{TE} / \mathrm{g}\right.$ for DPPH ${ }^{\bullet}$ and $224.59 \mathrm{mg} \mathrm{TE} / \mathrm{g}$ for ABTS $\left.{ }^{\bullet+}\right)$ and flower head extracts $\left(101.79 \mathrm{mg} \mathrm{TE} / \mathrm{g}\right.$ for $\mathrm{DPPH}^{\bullet}$ and $224.57 \mathrm{mg} \mathrm{TE} / \mathrm{g}$ for $\left.\mathrm{ABTS}^{\bullet+}\right)$ displayed the strongest abilities. The aerial parts extract had the lowest capacity in both scavenging assays. The reduction abilities of the studied herbal extracts were evaluated using the CUPRAC and FRAP methods, and they are closely linked to the electrohern-donating potential of the extracts. The most prominent reduction ability was observed in the roots, followed by the flower heads and aerial parts. In terms of reduction of Mo (VI) in the phosphomolybdenum (PHMD) assay, the extracts can be ranked as follow: roots > flower heads $>$ aerial parts. In general, the antioxidant data showed the same trends in total phenolic levels. This fact was supported by several authors who reported a strong correlation between total phenolics and radical scavenging and reducing abilities [31]. However, the metal chelating method based on the binding of transition metals by phytochemicals did not correlate with the other antioxidant methods. Regarding the metal chelating assay, the best ability was registered in the flower head extract (32.53 mg EDTAE/g), while the root sample was not active.

\subsection{Enzyme Inhibitory Effects}

Nowadays people are battling noncommunicable illnesses like diabetes mellitus, obesity and Alzheimer's. In particular, changes in lifestyle and dietary preferences increase the risk of these diseases. In the course of scientific study, some enzymes can be valuable tools against these health problems [32]. This approach is known as the enzyme inhibitory theory, in which some enzymes play a role in the pathologies of these diseases. For example, amylase and glucosidase are the main targets for controlling blood sugar levels in diabetes patients [33]. In addition, lipase is the main target for controlling obesity. In the present study, the inhibitory effects of different enzyme classes were investigated. Acetylcholinesterase (AChE) and butyrylcholinesterase (BChE) belong to the same structural class of proteins, the esterase/lipase family, amylase and glucosidase are hydrolases, while tyrosinase is an oxidoreductase enzyme. Given this information, several compounds have been chemically produced as inhibitors. Although they are accepted as effective agents in the control of global health problems, concerns have been raised regarding some disturbances to wellbeing [34]. In this regard, plants are considered to be the most important and richest natural source of enzyme inhibitors such as alkaloids, phenolic acids and terpenoids. Recent studies have shown that some plants and their constituents showed promising inhibitory effects on key enzymes that have been linked to significant health problems [35]. Hence, the enzyme inhibitory properties of $C$. appendiculatum extracts were examined (Table 3). In both AChE and BChE inhibition assays, the root extract exhibited the highest inhibitory values (4.93 mg GALAE/g and $3.80 \mathrm{mg}$ GALAE/g, respectively). The lowest abilities were recorded for aerial parts and flower head samples. Regarding 
tyrosinase inhibition ability, all extracts showed inhibitory effects, and the values ranged from 97.78 to $127.99 \mathrm{mg} \mathrm{KAE} / \mathrm{g}$ in the following order: flower heads < aerial parts < roots. All the tested herbal extracts had similar amylase inhibition capacity $(p>0.05)$, while the strongest glucosidase ability was observed in root extract $(0.72 \pm 0.07 \mathrm{mmolACAE} / \mathrm{g})$. In addition, the aerial parts sample was not active in glucosidase.

Table 3. Enzyme inhibitory properties of Cirsium appendiculatum extracts *.

\begin{tabular}{ccccc}
\hline Parts & $\begin{array}{c}\text { AChE Inhibition } \\
\text { (mgGALAE/g) }\end{array}$ & $\begin{array}{c}\text { BChE Inhibition } \\
\text { (mgGALAE/g) }\end{array}$ & $\begin{array}{c}\text { Tyrosinase } \\
\text { (mgKAE/g) }\end{array}$ & $\begin{array}{c}\text { Amylase } \\
\text { (mmolACAE/g) }\end{array}$ \\
\hline (mmolACAE/g)
\end{tabular}

* Values are expressed as mean \pm S.D ( $n: 3)$. GALAE: Galatamine equivalent; KAE: Kojic acid equivalent; ACAE: Acarbose equivalent; na: not active. Different letters $(\mathrm{a}, \mathrm{b}$ and $\mathrm{c})$ indicate significant differences in the extracts $(p<0.05)$

The data could be related to the different chemical components which were identified in the tested extracts (Table 1). For example, flavonoids and acylquinic acids dominate in the chemical profiles. Several flavonoids, including quercetin, luteolin and apigenin have been described as significant enzyme inhibitors [35]. In addition, chlorogenic acid and its derivatives are known to be important neuroprotectors and antidiabetic agents. Some data on the enzyme inhibitory properties of Cirsium species have been found [29]. Thus, the obtained data in the current study can be a valuable contribution to the development of new active substances agents against Alzheimer's disease, and diabetes and its complications. The methoxylated flavone derivatives pectolinarin and its aglycon pectolinarigenin are important for the pharmacological activity of the genus [8]. The aforementioned are responsible for the control of diabetes and other metabolic disorders, and are prominently represented in the chemical composition of C. japonicum [36]. Pectolinarin and its aglycone individually significantly reduce glucose levels, but the strongest antidiabetic effect is achieved when they are combined [36].

\subsection{Supervised Multivariate Analysis}

Taking into account the variation in quality and quantity of chemical compounds within the different parts of plants, we postulated that there would be variation in certain biological activities between the three studied parts of $C$. appendiculatum. In order to verify this hypothesis, we performed a supervised multivariate analysis. Partial least-square discriminant analysis (PLS-DA) is a commonly used technique for achieving classification models for sample discrimination and for identifying and excluding the less discriminant variables to include only the variables of interest. PLS-DA is particularly suitable for dealing with a much greater number of variables than observations and with multicollineality between those variables. Hence, this statistical approach was employed in an attempt to compare the different parts studied by considering all evaluated biological activities together. By referring to the results available in Figure 4A, a clear segregation of the three parts was observed, with excellent model robustness. Indeed, the sensitivity and specificity of the model when using the first two function were $100 \%$, which proved the accuracy of the PLS-DA model based on the biological activities for discriminating the three parts (Figure 4B). Afterwards, recourse to the variable selection method VIP (variable importance in projection) helped to identify the most discriminant biological activities responsible for the observed segregation (Figure $4 \mathrm{C}$ ). As part of the current study, biological activities having a VIP score above 1.2 were considered the most significant in parts separation. In this sense, the four biological activities (PHMD, CUPRAC, FRAP and glucosidase inhibition) having a VIP score above 1.2 on function 1 of the PLS-DA allowed a separation of the roots from the flower heads and aerial parts. On the other hand, only metal chelating (with VIP $=1.26$ on function 2 of PLS-DA) was the top biological activity which allowed a differentiation of the flower heads from both the roots and the aerial parts. In viewing the 
heat map, we noticed that among the studied herbal extracts, overall, the roots displayed the most potent biological activity and thus could be a promising source of biocompounds for the therapeutic industry (Figure 4D). The variability of the biological activities between the samples was corroborated by previous studies reporting that the biological activities of the given species may fluctuate between the organs due to the heterogeneous distribution of bioactive compounds between the organs [37]. For example, several investigations reported that condensed tannins exist widely in stems, while flavonoids are typically accumulated in flower tissues. Moreover, according to Trabelsi et al. [38], the heterogeneous distribution of bioactive compounds between the organs may be linked to the physiological roles of these different organs. That the highest number of biological activities occurred in the roots was not surprising given the abundance of total phenolic content compared with the flower heads and aerial parts. According to Fernandez et al. [39], the roots' bioactive compounds may be produced in response to soil-borne pathogens, i.e., insects and microbes. Additionally, the production of these compounds may be also due to indirect defense mechanisms against the root feeders of the other plants in the same environment.
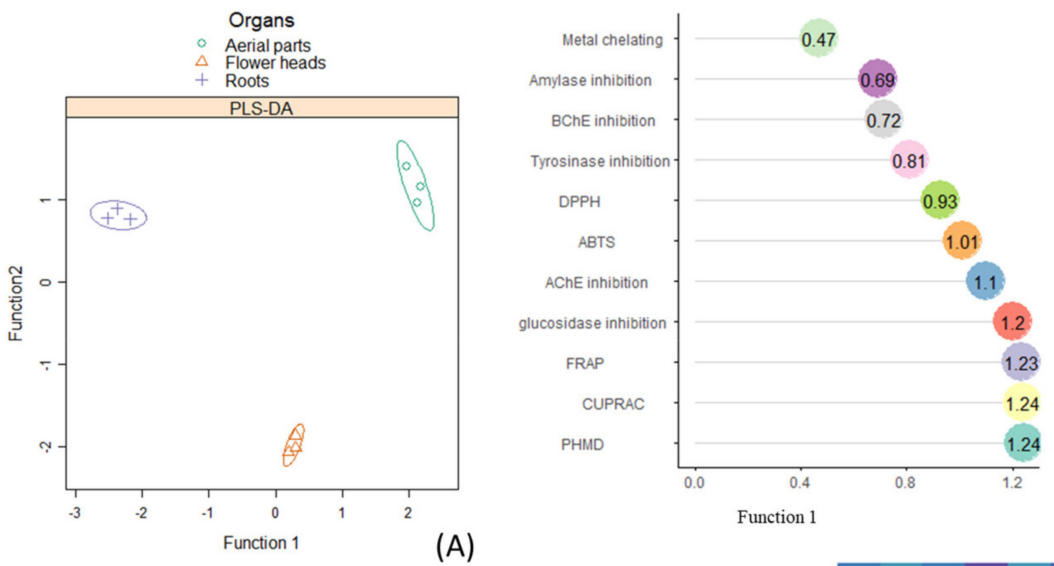

(A)

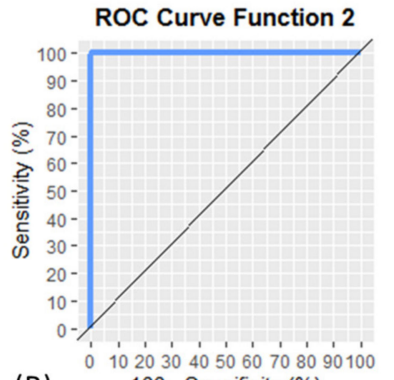

(B)

100 - Specificity $(\%)$

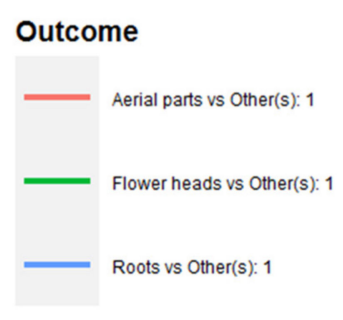

(D)

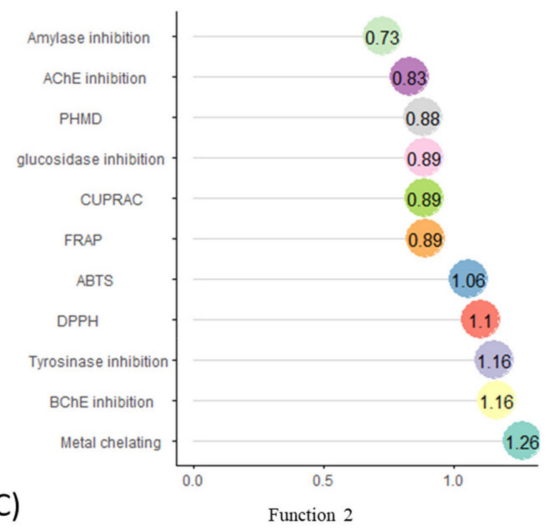

(C)

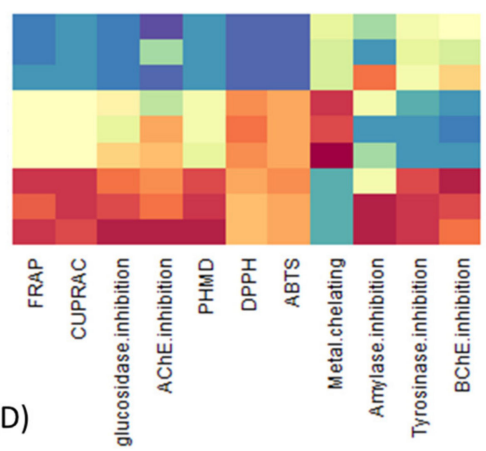

Figure 4. Partial least-square discriminant analysis graphical outputs on the biological activities (with three replications). (A) The sample plots. (B) Roc curve and AUC averaged using one-vs-all comparisons. (C) The most discriminant biological activities identified though VIP score calculation. (D) Heatmap displaying variation of biological activities between the three organs. Red color $=$ high activity. Blue color $=$ low activity.

\subsection{Relationship between Chemical Compounds and Biological Activities}

The contribution of the identified compounds to biological activities was assessed through Pearson's correlation. The results, depicted in Figure 5, showed several significant positive correlations between multiple biocompounds and various biological activities $(r>0.7)$. This could mean that different biocompounds were involved in the same biological activity as well as that a biocompound was involved in different biological activities. Thus, regarding the antioxidant assays, a synergistic or additive interaction is expected likely to occur between various compounds such as caffeic acid, protocatechuic acid, apigenin and quercetin, which have been proved to have excellent antioxidant properties. The strong antioxidant and enzyme-inhibitory activity of the root extract could be due to 
the presence of azelaic acid (53) and 3-hydroxyazelaic acid (55). Azelaic acid exhibits antioxidant and anti-inflammatory activity and is characterized by the influence of a number of enzymes, including tyrosinase, a key enzyme in melanogenesis. Azelaic acid affects inflammation by inhibiting the formation of free radicals (produced by neutrophils) and reducing the effects of reactive oxygen species, as well as inhibiting the peroxidation of arachidonic acid [40]. Phenolic compounds, widespread in Cirsium, determine the antioxidant activity of its species. Studies have shown that compounds such as cirsimaritin, hispidulin and cirsimarin are of major importance for the inhibitory ability of $C$. japonicum. Significant radical scavenging activity was observed as well as a protective effect against the lipid peroxidation of cell membranes, comparable to the antioxidant activity of vitamin E [9].

Hydroxybenzoic acids and their derivatives 1, 3, 9 and 15 and acylquinic acids 16-18 together with flavonoids $40,43,44$ and 49 could be considered the potential key constituents in the phenolic level. Flavon aglycones $(27,32,36)$ and glycosides $(39,46,49)$ together with quercetin (33) could be the most likely contributors to the flavonoid level. Herein, two flavonoids (34 and 38) were the most potent radical-scavenging flavonoids in $\mathrm{DPPH}^{\bullet}$ and $\mathrm{ABTS}^{\bullet+}$ assays. The results indicated that the aforementioned flavonoids along with $40,43,44$ and 49 contributed in reducing the power and the effect of the flavonoids that appeared to be higher than those of acylquinic acids, represented mainly by 16 and 18. In contrast, a series of flavon-hexuronides, 39,45 and 48 and hexosides 37 and 46 accompanied by the flavon aglycons $27,29,32$ and 36 were considered to have potential key metal chelating activity. Previous investigations revealed stronger antioxidant activity of 3,5-dicaffeoylquinic acid (IC50 $2.62 \mu \mathrm{g} / \mathrm{mL}$ for DPPH and $2.76 \pm 0.65 \mathrm{mM} \mathrm{TE} / \mathrm{mg}$ for FRRP) than chlorogenic acid and (IC50 $7.24 \mu \mathrm{g} / \mathrm{mL}$ for DPPH ${ }^{\bullet}$ and $2.21 \pm 0.14 \mathrm{mM} \mathrm{TE} / \mathrm{mg}$ for FRRP) [41]. In addition, DPPH ${ }^{\bullet}$ radical scavenging of luteolin ( $\mathrm{IC}_{50}$ of $53 \mu \mathrm{g} / \mathrm{mL}$ ) was found to be similar to those of Trolox $(36.9 \mu \mathrm{g} / \mathrm{mL})$. Moreover, luteolin is several times stronger than apigenin (even 20 times at $2.5 \mu \mathrm{g} / \mathrm{sample}$ ) [42]. Eucomic acid (7), one of the main components in the aerial parts and roots of $C$. appendiculatum, has a proven antioxidant effect.

As a phenolic compound, it is able to easily donate hydrogen atoms to free radicals, thus blocking the chain propagation step occurring in the oxidation process ( $\mathrm{H}$-atom transfer mechanism). On the other hand, 7 can give an electron to the free radical, turning it into a cation radical (a mechanism of free one-electron transfer). In addition, deprotonated carboxyl groups behave like electron-donor groups, thus contributing to $\mathrm{H}$-atom transfer and radical scavenging activity by electron donation [43]. 


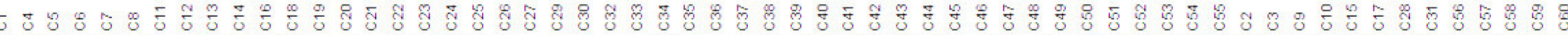

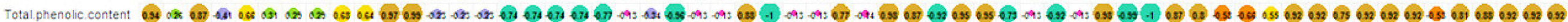

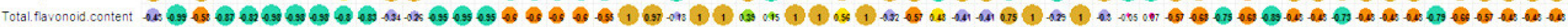

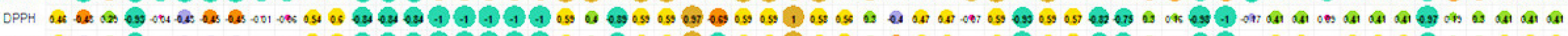

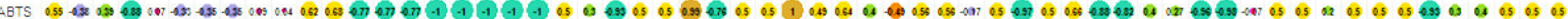

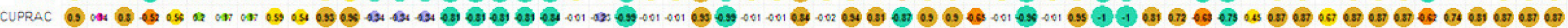

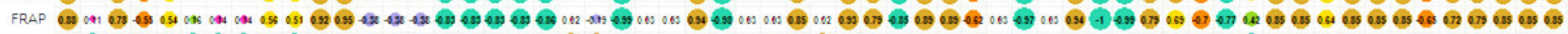

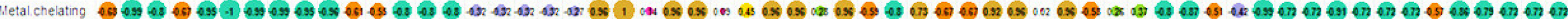

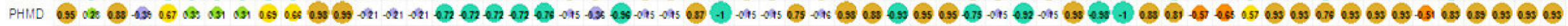

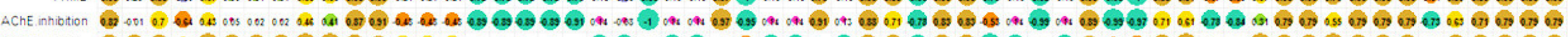

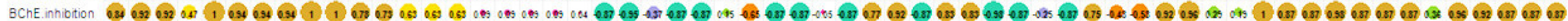

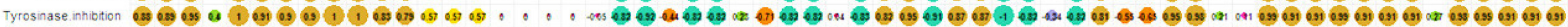

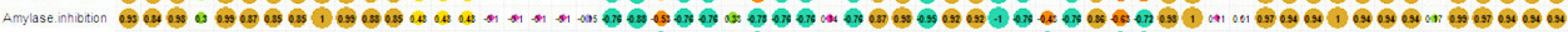

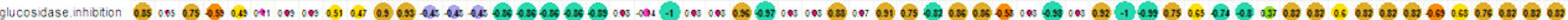

Figure 5. Correlation between evaluated biological activities and identified natural products. Brown color: $r=[0.71 ; 1]$; yellow color: $r=[0.42 ; 0.70]$; green color: $r=[0.16$; 0.41]; pink color: $r=[-0.14 ; 0.15]$; purple color: $r=[-0.43 ;-0.15]$; orange color: $r=[-0.71 ;-0.44]$; dark green color: $r=[-1 ;-0.72]$. 
In the same line, several compounds likely synergistically bind to the studied enzymes, i.e., tyrosinase, amylase, glucosidase as well as cholinesterase. Concerning AChE inhibitory activity, the analysis indicated that two acylquinic acids (16 and 18), two flavonoids (34 and 38) and two hydroxybenzoic acid-pentosides (10 and 15) intensively acted on the enzyme. Phenolic acids 2, 4 and 5 and hydroxybenzoic acid-hexosides 11-13 together with pectolinarin (52) and fatty acids 53 and 56-60 can pronouncedly inhibit BChE. Previously, acaciin and acacetin 7-O- $\beta$-D-galactopyranoside were found as the compounds responsible for the $\mathrm{AChE}$ inhibition. The relationship between structure and activity has revealed that the presence of methoxy groups at $\mathrm{C}-4^{\prime}$ in the $\mathrm{B}$ ring and a sugar at O-7 in ring $\mathrm{A}$ appeared to be essential for the inhibition of AChE [44]. In our study, eucomic acid (7), leonuriside A (14) and rutonosides of hispidulin and pectolinarigenin $(51,52)$ caused the most potent inhibition of tyrosinase. Interestingly, the aforementioned compounds were found among the inhibitors of $\alpha$-amylase. This is more plausible since Yu et al. [45] demonstrated that quercetin, ferulic acid and cinnamic acid synergistically inhibit tyrosinase. $p$-Coumaroyland caffeoylquinic acid (16 and 18) together with pectolinarigenin (34), kaempferol 3-Oglucoside (40) and acaciin (49) were involved in the inhibition of $\alpha$-glucosidase. In addition, pectolinarigenin and pectolinarin possess anti-inflammatory activity and they may inhibit eicosanoid formation in inflammatory lesions [46]. Azelaic acid (53), together with other dicarboxylic acids (C9-C12), has been shown to inhibit the enzyme tyrosinase, thereby directly affecting melanin biosynthesis. The effect of azelaic acid on the progression of malignant melanomas has been proven. Studies on cell cultures of keratinocytes, melanocytes and melanoma cells have shown the action of this acid as an inhibitor of DNA synthesis and cell proliferation. Azelaic acid reversibly inhibits thioredoxin reductase, a membranebound enzyme that is responsible for reducing free radicals in the epidermis and regulating melanin biosynthesis [47].

Consequently, it can be deduced from the findings that all observed biological activities depend on the concentration, the structure and the interaction between different bioactive compounds.

\section{Materials and Methods}

\subsection{Plant Material}

The plant material (whole samples of Cirsium appendiculatum with roots, aerial parts and flower heads) were collected on Vitosha Mt., "Zlatni mostove" locality at $1404 \mathrm{~m}$ a.s.l. $\left(42.41^{\circ} \mathrm{N} 23.23^{\circ} \mathrm{E}\right)$, during the full flowering stage in July 2018. The plant was identified by Reneta Gevrenova (Assoc. Prof. in the Department of Pharmacognosy, Faculty of Pharmacy, Medical University-Sofia) according to Stoyanov et al. [12]. A voucher specimen was deposited at the Herbarium Facultatis Pharmaceuticae Sophiensis, Medical UniversitySofia, Bulgaria (Voucher specimen № 11 615). Then, seven plant samples were separate into roots, aerial parts (stems and leaves) and flower heads dried at room temperature to constant weight. The dried plant materials were powdered using a laboratory mill.

\subsection{Sample Extraction}

Air-dried powdered roots, aerial parts (stems and leaves), and flower heads (15 g) were extracted with $80 \% \mathrm{MeOH}(1: 20 \mathrm{w} / v)$ by sonication $(80 \mathrm{kHz}$, ultra-sound bath Biobase UC-20C) for $15 \mathrm{~min}(\times 2)$ at room temperature. Then, the extracts were concentrated in vacuo and lyophilized (lyophilizer Biobase BK-FD10P) to yield crude extracts as follows: flower heads $3.54 \mathrm{~g}$, aerial parts $2.82 \mathrm{~g}$ and roots $2.14 \mathrm{~g}$. The lyophilized extracts $(1 \mathrm{mg})$ were dissolved in $80 \%$ methanol $(10 \mathrm{~mL})$. An aliquot $(2 \mathrm{~mL})$ of each extract solution was filtered through a $0.45 \mu \mathrm{m}$ syringe filter disc (Polypure II, Alltech, Lokeren, Belgium) and subjected to UHPLC-HRMS analyses.3.3. Chemicals

Acetonitrile and formic acid for LC-MS, and HPLC grade methanol were purchased from Fisher Scientific (Hampton, NY, USA).

The authentic standards used for compound identification were obtained as follows: gentisic acid, vanillic acid, protocatechuic acid, quercetin, luteolin, apigenin, genkwanin, 
apigenin 7-O-glucoside, kaempferol 3-O-glucoside, luteolin 7-O-glucoside and kaempferol 3-O-rutinoside, from Extrasynthese (Genay, France); caffeic acid, neochlorogenic acid, 3,4-dicaffeoylquinic acid, 1,5-dicaffeoylquinic acid and hispidulin were supplied from Phytolab (Vestenbergsgreuth, Germany); chlorogenic acid acaciin and pectolinarin were purchased from Sigma-Aldrich (St. Louis, MO, USA).

\subsection{UHPLC-HRMS}

Separation was achieved on a reversed phase column Waters Cortecs C18 $(2.7 \mu \mathrm{m}$, $2.1 \mathrm{~mm} \times 100 \mathrm{~mm}$ ), column maintained at $40{ }^{\circ} \mathrm{C}$. The binary mobile phase consisted of A: $0.1 \%$ formic acid in water and B: $0.1 \%$ formic acid in acetonitrile. The run time was $33 \mathrm{~min}$. The following gradient was used: the mobile phase was held at 5\% B for 1 min, gradually turned to $30 \%$ B over $19 \mathrm{~min}$, increased gradually to $50 \%$ B over $5 \mathrm{~min}$, increased gradually to $70 \%$ B over $5 \mathrm{~min}$ and finally increased gradually to $95 \%$ over $3 \mathrm{~min}$. The system was then turned to the initial condition of $5 \% \mathrm{~B}$ and equilibrated over $4 \mathrm{~min}$. The flow rate and the injection volume were set to $300 \mu \mathrm{L} / \mathrm{min}$ and $1 \mu \mathrm{L}$, respectively. The effluents were connected on-line with a Q Exactive Plus Orbitrap mass spectrometer, where the compounds were detected.

Mass analyses were carried out on a Q Exactive Plus mass spectrometer (Thermo Fisher Scientific, Inc., Waltham, MA, USA) equipped with a heated electrospray ionization (HESI-II) probe (Thermo Scientific). The tune parameters were as follows: spray voltage $-2.5 \mathrm{kV}$; sheath gas flow rate $38 \mathrm{AU}$; auxiliary gas flow rate $12 \mathrm{AU}$; spare gas flow rate $0 \mathrm{AU}$; capillary temperature $320^{\circ} \mathrm{C}$; probe heater temperature $32{ }^{\circ} \mathrm{C}$; and S-lens $\mathrm{RF}$ level 50. Acquisition was acquired at the full-scan MS and Data Dependent-MS ${ }^{2}$ modes. Full-scan spectra over the $\mathrm{m} / \mathrm{z}$ range 100 to 1500 were acquired in negative ionization mode at a resolution of 70,000. Other instrument parameters for Full MS mode were set as follows: automatic gain control (AGC) target 3e6, maximum injection time (IT) $100 \mathrm{~ms}$, number of scan ranges 1 . For the DD-MS ${ }^{2}$ mode, the instrument parameters were as follows: microscans 1, resolution 17,500, AGC target 1e5, maximum IT 50ms, MSX count 1, Top5, isolation window $2.0 \mathrm{~m} / z$, stepped normalized collision energy (NCE) 10, 20, $60 \mathrm{eV}$. Data acquisition and processing were carried out with Xcalibur 4.0 software (Thermo Scientific, Inc.).

\subsection{Total Phenolics and Flavonoid Contents Determination}

Total flavonoid and phenolic contents in the studied extracts were determined spectrophotometrically as described by Zengin and Aktumsek [48]. Standard compounds were used to express the obtained results (rutin (mg RE/g) for TFC and gallic acid (mg GAE/g) for TPC).

\subsection{Biological Activities Determination}

The metal chelating, phosphomolybdenum method (PHMD), ferric reducing antioxidant power (FRAP), cupric reducing antioxidant capacity (CUPRAC), 2,2'-azino-bis (3-ethylbenzothiazoline-6-sulphonic acid) $\left(\mathrm{ABTS}^{\bullet+}\right)$ and 2,2-diphenyl-1-picrylhydrazyl $\left(\mathrm{DPPH}^{\bullet}\right)$ scavenging activities of the extracts were evaluated as described by Grochowski et al. [49]. Positive controls were ethylenediaminetetraacetic acid (EDTA) for metal chelating and trolox (TE) for the other methods. The possible enzymatic inhibitory activities of the extracts against acetylcholinesterase (AChE), butyrylcholinesterase (BChE) (by Ellman's method), tyrosinase, $\alpha$-amylase and $\alpha$-glucosidase were assessed using bioassays [49].

\subsection{Data Processing}

Metabolite profiling using MZmine 2 software was applied to the UHPLC-HRMS raw files of the studied C. appendiculatum extracts. 


\subsubsection{Univariate Analysis}

All data were presented as mean $\pm \mathrm{SD}$, and the statistical analyses were performed by $\mathrm{R}$ software v. 3.6.1. The differences in the biological activities were assessed by using one-way ANOVA $(p<0.05)$.

\subsubsection{Supervised Multivariate Analysis}

Taking into account all the evaluated biological activities together, PLS-DA was conducted to discriminate the plant organs. The area under the receiver operating characteristic curve (ROC AUC) was plotted to identify the optimal number of functions of a model, allowing for better discrimination between the observations as well as the goodness of the model. The VIP score was calculated to identify the most discriminant biological activities.

\subsubsection{Pearson Correlation}

A correlation map was created to display the relationships between the bioactive compounds and the observed biological activities.

\section{Conclusions}

In conclusion, an integrated approach combining the UHPLC-HRMS profiling of specialized natural compounds of the Balkan thistle (Cirsium appendiculatum) with discriminant analysis of biological activity was developed. An Orbitrap-based mass spectrometry strategy was used for the annotation and dereplication of 61 specialized natural products including carboxylic, hydroxybenzoic, hydroxycinnamic and acylquinic derivatives, methoxylated flavonoids and fatty acids; all compounds are reported for the first time in the species. The partial least-square discriminant and heat-map analysis allowed an overview of the specialized natural products, bringing insight into herbal extract-specific patterns. The proposed biochemometric approach allowed the determination of the contribution of the identified metabolites from the extracts on biological activities without the isolation of individual compounds and it could be useful in the phytopharmacological investigation of poorly studied plants. The obtained results highlighted the potential benefits of $C$. appendiculatum root extract for the antioxidant response and enzyme objectives that are associated with worldwide health problems.

Supplementary Materials: The following are available online at https:/ / www.mdpi.com/article/10 .3390/plants10102046/s1, Table S1: Specialized natural products in Cirsium appendiculatum extracts; Figure S1: Variation of identified natural products between the Cirsium appendiculatum organs (flower heads, aerial parts and roots).

Author Contributions: Conceptualization, D.Z.-D. and R.G.; methodology, G.Z., G.A., K.I.S., M.F.M., V.B., A.S., P.N. and Y.V.; software, D.Z.-D., G.Z. and K.I.S.; validation, D.Z.-D. and R.G.; formal analysis, G.Z.; investigation, D.Z.-D. and G.Z.; resources, D.Z.-D.; data curation, G.Z.; writingoriginal draft preparation, D.Z.-D., G.Z. and R.G.; writing-review and editing, M.F.M.; visualization, D.Z.-D.; supervision, R.G.; project administration, D.Z.-D.; funding acquisition, D.Z.-D. All authors have read and agreed to the published version of the manuscript.

Funding: This research received no external funding.

Institutional Review Board Statement: Not applicable.

Informed Consent Statement: Not applicable.

Data Availability Statement: Not applicable.

Conflicts of Interest: The authors declare no conflict of interest.

\section{References}

1. Wolfender, J.-L.; Litaudon, M.; Touboul, D.; Queiroz, E.F. Innovative omics-based approaches for prioritisation and targeted isolation of natural products-new strategies for drug discovery. Nat. Prod. Rep. 2019, 36, 855-868. [CrossRef] 
2. Gevrenova, R.; Zheleva-Dimitrova, D.; Balabanova, V.; Voynikov, Y.; Sinan, K.I.; Mahomoodally, M.F.; Zengin, G. Integrated phytochemistry, bio-functional potential and multivariate analysis of Tanacetum macrophyllum (Waldst. \& Kit.) Sch. Bip. and Telekia speciosa (Schreb.) Baumg.(Asteraceae). Ind. Crop. Prod. 2020, 155, 112817.

3. Kadereit, J.W.; Jeffrey, C. Flowering Plants, Eudicots: Asterales. The Families and Genera of Vascular Plants, Volume VIII; Springer: Berlin/Heidelberg, Germany, 2007.

4. Yildiz, B.; Arabaci, T.; Dirmenci, T.; Köstekci, S. A taxonomic revision of the genus Cirsium Mill. sect. Cirsium (Asteraceae: Cardueae) in Turkey. Turk. J. Bot. 2016, 40, 514-530. [CrossRef]

5. Kim, M.S.; Nam, M.; Hwang, G.S. Metabolic alterations in two Cirsium species identified at distinct phenological stages using UPLC-QTOF/MS. Phytochem. Anal. 2018, 29, 77-86. [CrossRef]

6. Lee, S.; Lee, D.-H.; Kim, J.-C.; Um, B.H.; Sung, S.H.; Jeong, L.S.; Kim, Y.K.; Kim, S.-N. Pectolinarigenin, an aglycone of pectolinarin, has more potent inhibitory activities on melanogenesis than pectolinarin. Biochem. Biophys. Res. Commun. 2017, 493, 765-772. [CrossRef]

7. Abbet, C.; Slacanin, I.; Corradi, E.; De Mieri, M.; Hamburger, M.; Potterat, O. Comprehensive analysis of Cirsium spinosissimum Scop., a wild alpine food plant. Food Chem. 2014, 160, 165-170. [CrossRef]

8. Jordon-Thaden, I.E.; Louda, S.M. Chemistry of Cirsium and Carduus: A role in ecological risk assessment for biological control of weeds? Biochem. Syst. Ecol. 2003, 31, 1353-1396. [CrossRef]

9. Nazaruk, J.; Chłędzik, S.; Strawa, J.; Bazydło, K.; Wajs-Bonikowska, A. Chemical Composition and Antioxidant Activity of Cirsium vulgare Inflorescences. Nat. Prod. Commun. 2017, 12, 1934578X1701200414. [CrossRef]

10. Do, J.-C.; Jung, K.-Y.; Son, K.-H. Isolation of pectolinarin from the aerial parts of Cirsium nipponicum. Korean J. Pharmacogn. 1994, $25,73-75$.

11. Dutta, C.; Ray, L.P.; Roy, D. Taraxasterol and its derivatives from Cirsium arvense. Phytochemistry 1972, 11, 2267-2269. [CrossRef]

12. N. Stoyanov Stefanov, B.K. Flora Republicae Bulgaricae; Nauka i Izkustvo (Science and Art State Publishing House): Sofia, Bulgaria, 1967; Volume 2, pp. 1123-1128.

13. Wolfender, J.L.; Queiroz, E.F.; Allard, P.M. Massive metabolite profiling of natural extracts for a rational prioritization of bioactive natural products: A paradigm shift in pharmacognosy. Food Front. 2020, 1, 105-106. [CrossRef]

14. Termentzi, A.; Zervou, M.; Kokkalou, E. Isolation and structure elucidation of novel phenolic constituents from Sorbus domestica fruits. Food Chem. 2009, 116, 371-381. [CrossRef]

15. Chahdoura, H.; João, C.; Barros, L.; Santos-Buelga, C.; Ferreira, I.C.; Achour, L. Phytochemical characterization and antioxidant activity of Opuntia microdasys (Lehm.) Pfeiff flowers in different stages of maturity. J. Funct. Foods 2014, 9, 27-37. [CrossRef]

16. Ak, G.; Gevrenova, R.; Sinan, K.I.; Zengin, G.; Zheleva, D.; Mahomoodally, M.F.; Senkardes, I.; Brunetti, L.; Leone, S.; Di Simone, S.C. Tanacetum vulgare L.(Tansy) as an effective bioresource with promising pharmacological effects from natural arsenal. Food Chem. Toxicol. 2021, 153, 112268. [CrossRef]

17. Gai, X.-H. Research progress on chemical constituents of Coptidis Rhizoma and its pharmacological activities. Chin. Tradit. Herb. Drugs 2018, 4919-4927.

18. Münzenberger, B.; Heilemann, J.; Strack, D.; Kottke, I.; Oberwinkler, F. Phenolics of mycorrhizas and non-mycorrhizal roots of Norway spruce. Planta 1990, 182, 142-148. [CrossRef]

19. Lee, S.R.; Clardy, J.; Senger, D.R.; Cao, S.; Kim, K.H. Iridoid and phenylethanoid glycosides from the aerial part of Barleria lupulina. Rev. Bras. Farmacogn. 2016, 26, 281-284. [CrossRef]

20. Puppala, M.; Ponder, J.; Suryanarayana, P.; Reddy, G.B.; Petrash, J.M.; LaBarbera, D.V. The isolation and characterization of $\beta$-glucogallin as a novel aldose reductase inhibitor from Emblica officinalis. PLoS ONE 2012, 7, e31399. [CrossRef]

21. Clifford, M.N.; Wu, W.; Kirkpatrick, J.; Kuhnert, N. Profiling the chlorogenic acids and other caffeic acid derivatives of herbal Chrysanthemum by LC- MS n. J. Agric. Food Chem. 2007, 55, 929-936. [CrossRef]

22. Jaiswal, R.; Kiprotich, J.; Kuhnert, N. Determination of the hydroxycinnamate profile of 12 members of the Asteraceae family. Phytochemistry 2011, 72, 781-790. [CrossRef]

23. Justesen, U. Collision-induced fragmentation of deprotonated methoxylated flavonoids, obtained by electrospray ionization mass spectrometry. J. Mass Spectrom. 2001, 36, 169-178. [CrossRef]

24. Ren, D.; Ran, L.; Yang, C.; Xu, M.; Yi, L. Integrated strategy for identifying minor components in complex samples combining mass defect, diagnostic ions and neutral loss information based on ultra-performance liquid chromatography-high resolution mass spectrometry platform: Folium Artemisiae Argyi as a case study. J. Chromatogr. 2018, 1550, 35-44.

25. Zhang, X.; Liang, C.; Li, C.; Bu, M.; Bu, L.; Xiao, Y.; Sun, H.; Zhang, L. Simultaneous qualitative and quantitative study of main compounds in Commelina communis linn. by UHPLC-Q-TOF-MS-MS and HPLC-ESI-MS-MS. J. Chromatogr. Sci. 2018, 56, 582-594. [CrossRef]

26. De Souza, M.B., Jr.; Pinto, J.C.; Lima, E.L. Control of a chaotic polymerization reactor: A neural network based model predictive approach. Polym. Eng. Sci. 1996, 36, 448-457. [CrossRef]

27. Rashmi, H.B.; Negi, P.S. Phenolic acids from vegetables: A review on processing stability and health benefits. Food Res. Int. 2020, 136, 109298. [CrossRef]

28. Nazaruk, J. Antioxidant activity and total phenolic content in Cirsium five species from north-east region of Poland. Fitoterapia 2008, 79, 194-196. [CrossRef] 
29. Llorent-Martínez, E.J.; Zengin, G.; Sinan, K.I.; Polat, R.; Canll, D.; Picot-Allain, M.C.N.; Mahomoodally, M.F. Impact of different extraction solvents and techniques on the biological activities of Cirsium yildizianum (Asteraceae: Cynareae). Ind. Crop. Prod. 2020, 144, 112033. [CrossRef]

30. Sánchez-Rangel, J.C.; Benavides, J.; Heredia, J.B.; Cisneros-Zevallos, L.; Jacobo-Velázquez, D.A. The Folin-Ciocalteu assay revisited: Improvement of its specificity for total phenolic content determination. Anal. Methods 2013, 5, 5990-5999. [CrossRef]

31. Wu, L.; Wu, W.; Cai, Y.; Li, C.; Wang, L. HPLC fingerprinting-based multivariate analysis of phenolic compounds in mango leaves varieties: Correlation to their antioxidant activity and in silico $\alpha$-glucoidase inhibitory ability. J. Pharm. Biomed. Anal. 2020, 191, 113616. [CrossRef]

32. Ramsay, R.R.; Tipton, K.F. Assessment of enzyme inhibition: A review with examples from the development of monoamine oxidase and cholinesterase inhibitory drugs. Molecules 2017, 22, 1192. [CrossRef]

33. Tan, Y.; Chang, S.K. Digestive enzyme inhibition activity of the phenolic substances in selected fruits, vegetables and tea as compared to black legumes. J. Funct. Foods 2017, 38, 644-655. [CrossRef]

34. Papoutsis, K.; Zhang, J.; Bowyer, M.C.; Brunton, N.; Gibney, E.R.; Lyng, J. Fruit, vegetables, and mushrooms for the preparation of extracts with $\alpha$-amylase and $\alpha$-glucosidase inhibition properties: A review. Food Chem. 2020, 338, 128119.

35. Yener, I.; Kocakaya, S.O.; Ertas, A.; Erhan, B.; Kaplaner, E.; Oral, E.V.; Yilmaz-Ozden, T.; Yilmaz, M.A.; Ozturk, M.; Kolak, U. Selective in vitro and in silico enzymes inhibitory activities of phenolic acids and flavonoids of food plants: Relations with oxidative stress. Food Chem. 2020, 327, 127045. [CrossRef]

36. Liao, Z.; Chen, X.; Wu, M. Antidiabetic effect of flavones from Cirsium japonicum DC in diabetic rats. Arch. Pharmacal Res. 2010, 33, 353-362. [CrossRef]

37. Zengin, G.; Ceylan, R.; Sinan, K.I.; Ak, G.; Uysal, S.; Mahomoodally, M.F.; Lobine, D.; Aktumsek, A.; Cziáky, Z.; Jeko, J. Network analysis, chemical characterization, antioxidant and enzyme inhibitory effects of foxglove (Digitalis cariensis Boiss. ex Jaub. \& Spach): A novel raw material for pharmaceutical applications. J. Pharm. Biomed. Anal. 2020, 191, 113614.

38. Trabelsi, N.; Falleh, H.; Jallali, I.; Daly, A.B.; Hajlaoui, H.; Smaoui, A.; Abdelly, C.; Ksouri, R. Variation of phenolic composition and biological activities in Limoniastrum monopetalum L. organs. Acta Physiol. Plant. 2012, 34, 87-96. [CrossRef]

39. Fernandez, C.; Monnier, Y.; Ormeño, E.; Baldy, V.; Greff, S.; Pasqualini, V.; Mévy, J.-P.; Bousquet-Mélou, A. Variations in allelochemical composition of leachates of different organs and maturity stages of Pinus halepensis. J. Chem. Ecol. 2009, 35, 970-979. [CrossRef]

40. Jones, D.A. Rosacea, reactive oxygen species, and azelaic acid. J. Clin. Aesthetic Dermatol. 2009, 2, 26.

41. Zheleva-Dimitrova, D.; Gevrenova, R.; Zaharieva, M.M.; Najdenski, H.; Ruseva, S.; Lozanov, V.; Balabanova, V.; Yagi, S.; Momekov, G.; Mitev, V. HPLC-UV and LC-MS Analyses of Acylquinic Acids in Geigeria alata (DC) Oliv. \& Hiern. and their Contribution to Antioxidant and Antimicrobial Capacity. Phytochem. Anal. 2017, 28, 176-184.

42. Majewska, M.; Skrzycki, M.; Podsiad, M.; Czeczot, H. Evaluation of antioxidant potential of flavonoids: An in vitro study. Acta Pol. Pharm. 2011, 68, 611-615.

43. Petruk, G.; Di Lorenzo, F.; Imbimbo, P.; Silipo, A.; Bonina, A.; Rizza, L.; Piccoli, R.; Monti, D.M.; Lanzetta, R. Protective effect of Opuntia ficus-indica L. cladodes against UVA-induced oxidative stress in normal human keratinocytes. Bioorg. Med. Chem. Lett. 2017, 27, 5485-5489. [CrossRef]

44. Lim, S.-S.; Han, S.-M.; Kim, S.-Y.; Bae, Y.-S.; Kang, I.-J. Isolation of acetylcholinesterase inhibitors from the flowers of Chrysanthemum indicum Linne. Food Sci. Biotechnol. 2007, 16, 265-269.

45. Yu, Q.; Fan, L.; Duan, Z. Five individual polyphenols as tyrosinase inhibitors: Inhibitory activity, synergistic effect, action mechanism, and molecular docking. Food Chem. 2019, 297, 124910. [CrossRef]

46. Lim, H.; Son, K.H.; Chang, H.W.; Bae, K.; Kang, S.S.; Kim, H.P. Anti-inflammatory activity of pectolinarigenin and pectolinarin isolated from Cirsium chanroenicum. Biol. Pharm. Bull. 2008, 31, 2063-2067. [CrossRef]

47. Schallreuter, K.; Wood, J. A possible mechanism of action for azelaic acid in the human epidermis. Arch. Dermatol. Res. 1990, 282, 168-171. [CrossRef]

48. Zengin, G.; Aktumsek, A. Investigation of antioxidant potentials of solvent extracts from different anatomical parts of Asphodeline anatolica E. Tuzlaci: An endemic plant to Turkey. Afr. J. Tradit. Complementary Altern. Med. 2014, 11, 481-488. [CrossRef]

49. Grochowski, D.M.; Uysal, S.; Aktumsek, A.; Granica, S.; Zengin, G.; Ceylan, R.; Locatelli, M.; Tomczyk, M. In vitro enzyme inhibitory properties, antioxidant activities, and phytochemical profile of Potentilla thuringiaca. Phytochem. Lett. 2017, 20, 365-372. [CrossRef] 